\title{
THE CALAMUS JAVENSIS (ARECACEAE: CALAMOIDEAE) COMPLEX IN HISTORICAL BIOGEOGRAPHIC CONTEXT
}

\author{
Received January 31, 2021; accepted March 1, 2021
}

\author{
MEGA ATRIA \\ Departemen Biologi, Fakultas Matematika dan Ilmu Pengetahuan Alam, Universitas Indonesia (UI), Depok 16424, \\ Indonesia. \\ Naturalis Biodiversity Center, Research Group of Tropical Botany, P.O. Box 9517, 2300 RA Leiden, the Netherlands. \\ Institute of Biology Leiden, Leiden University, P.O. Box 9505, 2300 RA Leiden, the Netherlands. \\ Email:mega.atria@sci.ui.ac.id
}

\section{PETER C. VAN WELZEN}

Naturalis Biodiversity Center, Research Group of Tropical Botany, P.O. Box 9517, 2300 RA Leiden, the Netherlands. Institute of Biology Leiden, Leiden University, P.O. Box 9505, 2300 RA Leiden, the Netherlands.

Email: peter.vanwelzen@naturalis.com

\begin{abstract}
ATRIA, M. \& VAN WELZEN, P. C. 2021. The Calamus javensis (Arecaceae: Calamoideae) complex in historical biogeographic context. Reinwardtia 20(1): 1-7. - Calamus javensis is a very polymorphic species with a number of recognisable forms (of which several were once even recognized at species level). A historical biogeographic analysis showed no historical distribution pattern in the diversification of these various forms. The forms are very likely the result of adaptation to local circumstances, whereby more or less identical forms can develop under similar niche circumstances in disjunct areas, exceptions are the 'acuminatus-polyphyllus' form and C. tenompokensis that are recognisable and present in a non-disjunct area.
\end{abstract}

Key words: Arecaceae, Calamus javensis, historical biogeography, species complex, taxonomy.

\begin{abstract}
ABSTRAK
ATRIA, M. \& VAN WELZEN, P. C. 2021. Jenis Calamus javensis (Arecaceae: Calamoideae) kompleks dalam hubungan sejarah biogeografi. Reinwardtia 20(1): 1-7. - Calamus javensis adalah jenis yang sangat polimorfik dengan sejumlah bentuk yang dapat dikenali (beberapa di antaranya telah dikenali pada tingkat jenis). Analisis sejarah biogeografi tidak menunjukkan adanya pola distribusi sejarah dalam proses diversifikasi berbagai bentuk tersebut. Bentuk-bentuk tersebut kemungkinan besar merupakan hasil adaptasi terhadap keadaan lingkungan lokal, dan bentukbentuk yang kurang lebih memiliki kesamaan morfologi merupakan hasil dari proses adaptasi terhadap relung ekologi yang sama di daerah yang terpisah secara geografi. Bentuk 'acuminatus-polyphyllus' dan C. tenompokensis merupakan pengecualian karena mudah dikenali dan terdapat di area nondisjungsi.
\end{abstract}

Kata kunci: Arecaceae, Calamus javensis, jenis kompleks, sejarah biogeografi, taksonomi.

\section{INTRODUCTION}

Presently, the largest genus in the rattans, climbing palms, is Calamus L. (subfam. Calamoideae) with ca. 400 species (Henderson, 2020). Especially since phylogenetic analyses (Kramadibrata, 1992; Baker et al., 2000a \& 2000b) proved it to be paraphyletic with the genera Ceratolobus Blume ex Schult. \& Schult.f., Daemonorops Blume, Pogonotium J.Dransf. and Retispatha J.Dransf. nested within it, which Baker (2015) synonymized with Calamus.

Within Calamus, C. javensis Blume is a slender, very polymorphic rattan commonly present in the everwet rainforests of southeast Asian. In the course of time many taxa have been split from it and various forms are recognizable (see names in Table 1 and Fig. 2). Most of the names have been synonymized again with $C$. javensis (Barford \& Dransfield, 2013; Henderson, 2020). Within the complex only C. tenompokensis Furtado proved to be recognizable, in a morphometric, phenetic analysis (Atria et al., 2017) as well as in a specimen level phylogenetic analysis (Atria et al., 2020). This species is generally an accepted taxon (Henderson, 2020). Unfortunately, the phylogenetic analysis (Atria et al., 2020), based on two markers (the chloroplast matK and the nuclear 5S), gave no real satisfying resolution for most specimens in the analysis. Only the $5 \mathrm{~S}$ marker provided some structure in the cladogram in which most branches were not supported (in Fig. 2 the highly supported groups are indicated as groups $\mathrm{A}-\mathrm{H}$ ).

Typical for all forms of $C$. javensis is a stem diameter of 2-6 $\mathrm{mm}$ without leaf sheaths and to 10 $\mathrm{mm}$ with sheaths; internodes up to $30 \mathrm{~cm}$ long (usually shorter); a distinct ocrea, deep crimson when young; pinnate, ecirrate leaves to $40 \mathrm{~cm}$ long, flabellate terminal leaflets and the lowermost pair often swept back across the stem; a flagellum 


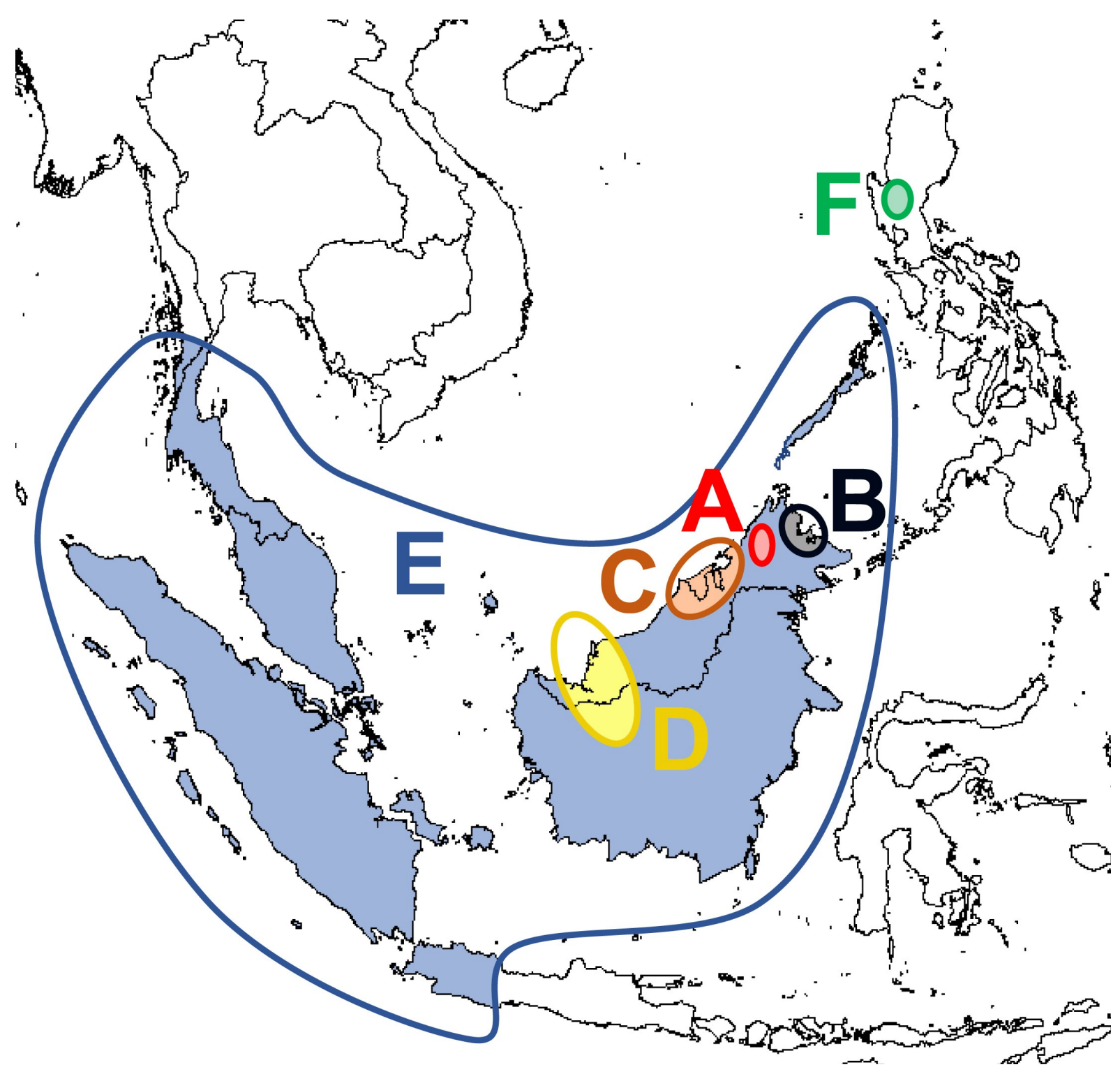

Fig. 1. Areas as used in the historical biogeographic analysis. $A=N W$ Sabah (Borneo). $B=$ NE Sabah (Borneo). C = Brunei with small parts of N Sarawak and SE Sabah (Borneo). D = central part of Sarawak and part of Kalimantan Barat (Borneo). $\mathrm{E}=$ remaining area, surrounding many of the former ones ( $\mathrm{S}$ Thailand/S Myanmar up to Java and rest of Borneo). $\mathrm{F}=$ Central Luzon (Philippines).

to $75 \mathrm{~cm}$ long, long inflorescences with red rachillae and ripe fruits ovoid in shape. Calamus tenompokensis can be distinguished from the $C$. javensis complex by its short stem, angular petiole and rachis, a very different leaf sheath appearance (the sheaths being massive and robust), number ( 9 pairs) and almost always regularly arrangement of the leaflets, staminate calyx swollen (versus not swollen in C. javensis), pistillate inflorescences with rachilla bracts with a broadly cupuliform limb (versus bracts tightly sheathing in $C$. javensis).

One other form is phenetically and phylogenetically rather distinct, 'acuminatus' (to be united with form 'polyphyllus'); will be recognized as a variety of $C$. javensis (Atria et al., ms., to be sub- mitted, see there for justification). This taxon always has many (9-12) narrow or linear leaflets, subequidistant to regularly arranged, subopposite and with a smooth or almost smooth leaf sheath. The inflorescences resemble those of form javensis, but those are mostly smaller or finer. The size of flowers and fruits is smaller, and the bracts of the peduncle are more cupuliform than form javensis.

The biogeographical range of the $C$. javensis complex includes southern Thailand, the Malay Peninsula, Sumatra, West Java, Borneo and Luzon in the Philippines (Fig. 1). The greatest morphological diversity is found in north Borneo. The aim of this study is to see if historical 
Table 1. Distribution area (Fig. 1) of the samples used in the phylogenetic analysis (Atria et al., 2020). The group names (column 1) refer to mainly informal groups within C. javensis except for C. tenompokensis (recognized as species) and acuminatus (to be recognized as variety polyphyllus within $C$. javensis). All vouchers are in L (Naturalis Biodiversity Center, Leiden, the Netherlands) except SAN 21064 in K (Royal Botanic Gardens Kew, UK).

\begin{tabular}{|c|c|c|c|c|}
\hline Group name & $\begin{array}{l}\text { Reference to } \\
\text { molecular } \\
\text { sample }\end{array}$ & Area & Voucher & Location \\
\hline acuminatus & $10 \mathrm{~A}$ & $\mathrm{~B}$ & Mega MAT 037 & Sabah \\
\hline acuminatus & $10 \mathrm{~B}$ & $\mathrm{~B}$ & Mega MAT 028 & Sabah \\
\hline acuminatus & $10 \mathrm{C}$ & $\mathrm{C}$ & SAN 85869 & Sabah \\
\hline acuminatus & $10 \mathrm{D}$ & $\mathrm{C}$ & SAN 126575 & Sabah \\
\hline acuminatus & $10 \mathrm{E}$ & $\mathrm{B}$ & Mega MAT 033 & Sabah \\
\hline acuminatus & $6 \mathrm{G}$ & $\mathrm{C}$ & Dransfield JD 5584 & Sabah \\
\hline amplijugus & $1 \mathrm{E}$ & $\mathrm{C}$ & Mega MAT 109 & Brunei \\
\hline amplijugus & $3 \mathrm{D}$ & $\mathrm{B}$ & Mega MAT 045 & Sabah \\
\hline amplijugus & $3 \mathrm{~F}$ & $\mathrm{C}$ & Mega MAT 109C & Brunei \\
\hline congestiflorus & $12 \mathrm{E}$ & $\mathrm{C}$ & Mega MAT 079 & Sabah \\
\hline corrugatus & $6 \mathrm{C}$ & $\mathrm{D}$ & Dransfield JD 6080 & Sarawak \\
\hline corrugatus & $6 \mathrm{E}$ & $\mathrm{D}$ & Mogea 3615 & Central Kalimantan \\
\hline corrugatus & $6 \mathrm{~F}$ & $\mathrm{D}$ & Dransfield JD 5868 & Sarawak \\
\hline elopurensis & $10 \mathrm{~F}$ & $\mathrm{~B}$ & Dransfield JD 6265 & Sabah \\
\hline Form2 & $8 \mathrm{E}$ & $\mathrm{F}$ & Madulid et al. 7172 & Luzon \\
\hline Form4 & $11 \mathrm{G}$ & $\mathrm{B}$ & Chew \& Corner RSNB 4835 & Sabah \\
\hline Form4 & $12 \mathrm{D}$ & A & Mega MAT 065 & Sabah \\
\hline impar & $11 \mathrm{~A}$ & $\mathrm{E}$ & Ave 136 & Malay Peninsula \\
\hline impar & $11 \mathrm{~B}$ & $\mathrm{E}$ & Niyomdham 1254 & S. Thailand \\
\hline impar & $11 \mathrm{D}$ & $\mathrm{A}$ & SAN 21064 & Sabah \\
\hline javensis & $1 \mathrm{~A}$ & $\mathrm{E}$ & Mega MAT 001 & W. Java \\
\hline javensis & $1 \mathrm{~B}$ & $\mathrm{C}$ & Mega MAT 093 & Brunei \\
\hline javensis & $1 \mathrm{C}$ & $\mathrm{E}$ & Mega MAT 022 & W. Java \\
\hline javensis & $1 \mathrm{D}$ & $\mathrm{E}$ & Mega MAT 008 & W. Java \\
\hline javensis & $1 \mathrm{~F}$ & $\mathrm{E}$ & Mega MAT 011 & W. Java \\
\hline javensis & $1 \mathrm{G}$ & $\mathrm{E}$ & Mega MAT 005 & W. Java \\
\hline javensis & $2 \mathrm{C}$ & $\mathrm{C}$ & Mega MAT $100 B$ & Brunei \\
\hline javensis & $2 \mathrm{E}$ & $\mathrm{E}$ & Mega MAT 024 & W. Java \\
\hline javensis & $3 \mathrm{G}$ & $\mathrm{E}$ & Mega MAT 007 & W. Java \\
\hline javensis & $3 \mathrm{H}$ & $\mathrm{E}$ & Mega MAT 002 & W. Java \\
\hline javensis & $4 \mathrm{~A}$ & $\mathrm{E}$ & Ave 114 & Malay Peninsula \\
\hline javensis & $4 \mathrm{~B}$ & $\mathrm{D}$ & Dransfield JD 4728 & Sarawak \\
\hline javensis & $4 \mathrm{C}$ & $\mathrm{E}$ & Ambri \& Arifin $W 915$ & E. Kalimantan \\
\hline javensis & $4 \mathrm{D}$ & $\mathrm{E}$ & Kato \& Wiriadinata B 4943 & E. Kalimantan \\
\hline javensis & $4 \mathrm{H}$ & $\mathrm{D}$ & Dransfield JD 4650 & Sarawak \\
\hline javensis & $5 \mathrm{~A}$ & $\mathrm{E}$ & Dransfield JD 4519 & Malay Peninsula \\
\hline javensis & $5 \mathrm{~B}$ & $\mathrm{C}$ & $S 50593$ & Sarawak \\
\hline javensis & $5 \mathrm{E}$ & $\mathrm{E}$ & Dransfield JD 3613 & Sumatra \\
\hline javensis & $6 \mathrm{~A}$ & $\mathrm{D}$ & $S 54137$ & Sarawak \\
\hline javensis & $6 \mathrm{~B}$ & $\mathrm{E}$ & van Valkenbrg 1320 & E. Kalimantan \\
\hline javensis & $7 \mathrm{~A}$ & $\mathrm{E}$ & Mega MAT 097 & Brunei \\
\hline javensis & $7 \mathrm{C}$ & $\mathrm{C}$ & $S 52424$ & Sarawak \\
\hline javensis & $7 \mathrm{~F}$ & $\mathrm{E}$ & Dransfield JD 2553 & Sumatra \\
\hline javensis & $8 \mathrm{~B}$ & $\mathrm{E}$ & Mega MAT 057 & Sabah \\
\hline javensis & $8 \mathrm{D}$ & $\mathrm{E}$ & Ave 216 & Malay Peninsula \\
\hline polyphyllus & $2 \mathrm{~B}$ & $\mathrm{C}$ & Mega MAT 103A & Brunei \\
\hline polyphyllus & $3 \mathrm{C}$ & A & Mega MAT 058 & Sabah \\
\hline polyphyllus & $10 \mathrm{G}$ & $\mathrm{B}$ & Mega MAT 027 & Sabah \\
\hline polyphyllus & $12 \mathrm{~B}$ & $\mathrm{C}$ & Mega MAT 095 & Brunei \\
\hline polyphyllus & $12 \mathrm{C}$ & $\mathrm{E}$ & Mega MAT 080 & Sabah \\
\hline tenompokensis & $10 \mathrm{H}$ & A & Mega MAT 055 & Sabah \\
\hline tenompokensis & $11 \mathrm{E}$ & $\mathrm{A}$ & Mega MAT 054 & Sabah \\
\hline
\end{tabular}


geographic patterns developed in the various forms.

\section{MATERIALS AND METHODS}

The results of the phylogenetic analysis (Fig. 2; Atria et al., 2020) formed the basis for the historical biogeographic analysis. At first we opted for a phylogeographic analysis, as this provides better methodology for intraspecific relationships, but the signal in the molecular data was too weak. Therefore, only a simple historical biogeography analysis was the only alternative left. A total of 52 samples was used to sequence the nuclear $5 \mathrm{~S}$ spacer and the chloroplast matK regions. All samples, molecular methodology and phylogenetic methods are explained in Atria et al. (2020). Calamus flabellatus Becc. (silica sample) acted as outgroup in the phylogenetic parsimony and Bayesian phylogenetic analyses. The outgroup was removed again in the historical biogeography as it was unknown how closely related the Calamus flabellatus is to $C$. javensis.

\section{Taxon sampling}

The 52 samples of silica gel-dried leaf fragments and herbarium specimens comprised one of the syntypes, from west Java (Blume s.n. (L, sheet 900.182-94)), while also silica gel-dried material from the type locality was included. All samples cover the distribution area of the $C$. javensis complex. A list of voucher specimens can be found in Appendix 1 of Atria et al. (2020).

\section{Areas}

Areas are recognized via a combination of the distribution of informal groups (names in the phylogeny, Fig. 2; Atria et al., 2020) and supported monophyletic groups. The latter were very rare (indicated with letters A-H in Fig. 2) and, therefore, the specimens in all non-supported branches ended up in area E. The selection process resulted in the discrimination of the following areas (Fig. 1): $A=N W$ Sabah (Borneo), B = NE Sabah (Borneo), $\mathrm{C}=$ Brunei with small parts of $\mathrm{N}$ Sarawak and SE Sabah (Borneo), D = central part of Sarawak and part of Kalimantan Barat (Borneo), $\mathrm{E}=$ remaining area, surrounding many of the former ones (S Thailand/S Myanmar up to Java and rest of Borneo), $\mathrm{F}=$ Central Luzon (Philippines). Table 1 shows the areas as per specimen.

\section{Historical Biogeographic Analysis}

All analyses were carried out in RASP v.4.0 (Reconstruct Ancestral State in Phylogenies; Yu et al., 2015). Three modules in RASP were used: parsimony-based S-DIVA (Statistical, DIspersalVIcariance analysis; Ronquist, 1997), maximum likelihood based DEC (Dispersal Extinction Cladogenesis; Ree et al., 2005; Ree \& Smith, 2008) and S-DEC (Statistical DEC). As input all cladograms $(18,000$, burn-in removed) found with a bayesian phylogeny analysis (Atria et al., 2020) were used and the Maximum Clade Credibility (MCC) tree derived from those cladograms. DEC only uses the MCC tree for the analysis, the Statistical modules reconcile all trees against the MCC tree, thus introducing a kind of consensus per branch in the MCC tree (and adding a more Bayesian approach to DIVA).

In all modules the number of areas allowed per node was increased from 2 to 6 (maximum possible) per analysis. All other settings were default, no additional time frames were added in DEC as the MCC tree (Atria et al., 2020) was not dated.

\section{RESULTS}

The results of all analyses are summarized in Fig. 2 for the maximum number of areas (6) per node. Even though more areas were allowed, at most only 3 areas resulted as best optimisation per node, but usually 2 or a single area proved to be the best results. As could be expected, these optimisations, independent of the method, generally include area $\mathrm{E}$ as this is by far the largest surface and most specimens have this distribution. The areas mentioned per node (Fig. 2) are the ones with the highest probabilities, but as most node support was very low, therefore, these highest probabilities are also low and often many possible optimisations per node exist (not shown).

Even though most specimens occurred in area $\mathrm{E}$, Borneo (areas A-D) is very important. In the upper clade (Fig. 2, nodes 54-67, containing the groups D-H) especially area B (NE Sabah), is important, followed by areas A (Kinabalu and adjacent areas) and C ("Brunei"). In the other clade (Fig. 2, nodes 68-103) these are especially areas C and D (central Sarawak, part of Kalimantan Barat) on Borneo. Of course area E comprises, among other areas, the rest of Borneo. No other obvious patterns were visible per form name or in most clades.

Of the groups that can be recognized it is obvious that C. tenompokensis (Fig. 2, group E) is only present in area A. The only other taxon is C. javensis var. polyphyllus (Fig. 2, mainly group F), which occurs in the Bornean areas B and C. Unfortunately, only represented once in the phylogeny, is 'Form 2', the only one found in in central Luzon, the Philippines (Fig. 2, halfway, blue).

\section{DISCUSSION}

The basal node (Fig. 2, node 104) indicates as best optimisation area $\mathrm{BCE}$ or $\mathrm{BE}$, but these areas 


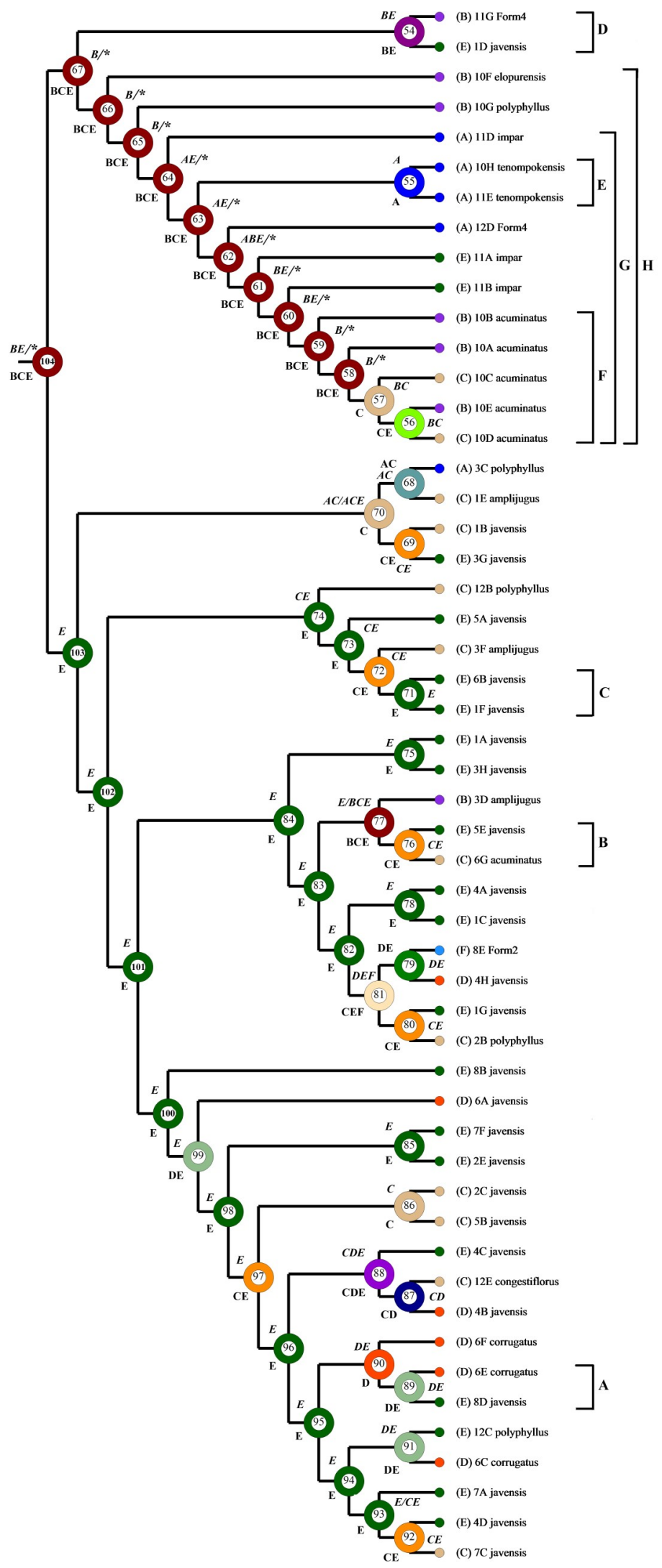

Fig. 2. Area cladogram for the Calamus javensis complex. The groups indicated are the ones with a high ( 0.85 posterior probability) in the phylogenetic analysis (Atria et al., 2020). The terminal taxa have their distribution between brackets in front of the name. The various areas can be found in Fig. 1. On the internal nodes the optimisations according to S-DIVA (bold), DEC (bold italics) and S-DEC (if similar to DEC then only one value, otherwise behind the /). 
cannot be regarded as the area of origin of $C$. javensis. For that purpose this phylogeny should be embedded in a much larger phylogeny, preferably the whole of Calamus (which has to include more markers than the phylogeny used here). Borneo is one of the oldest areas in $\mathrm{W}$ Malesia that was already (partly) above water more than 60 Ma (Hall, 2013), especially the southern part. This in combination with the high variability on Borneo may indicate that perhaps the species originated on Borneo, but at least it was already present on the island in an early phase of its evolution. The root node Calamus in Janssens et al. (2020) is ca. $60 \mathrm{Ma}$, when at least the southern part of Borneo was above water (Hall, 2013).

Of the three rainforest areas in the world Malesia differs from Amazonia and the Congo rainforest. During interglacial periods, like the present, the latter two occupy their largest surface area, while Malesia is then at its smallest (e.g., Morley \& Flenley, 1987; Cannon et al., 2009). During glacial periods this reverses, drought reduces the rainforest areas in Amazonia and the Congo to refuge areas, while the forest in Malesia extends to its maximum due to the emergence of a dry Sunda Shelf (connecting the Malay Peninsula, Sumatra, Borneo and Java) and Sahul Shelf (connecting New Guinea to Australia). However, not the whole Sunda Shelf becomes an everwet area during glacial periods, a large savannah corridor (complete extend unknown: Cannon et al., 2009) develops from the Malay Peninsula via the lowest areas towards Java and involves the southern part of Borneo. NE Borneo (area B) often acts as a refuge area for species, as shown for the Dipterocarpaceae by Raes et al. (2014) via species distribution modelling for the last glacial maximum (21 kya). This might also have been an important refuge area for Calamus javensis, as area $\mathrm{B}$ is important in the upper clade (Fig. 2, nodes 54-67).

Calamus tenompokensis (group E in Fig. 2) is typically a local endemic that originated at the higher altitudes of Mount Kinabalu and the Crocker Range in NE Sabah (area A). Something similar applies to the 'acuminatus' form (group F in Fig. 2), but the ecological conditions under which the form develops are less obvious. It occurs in areas B (NE Sabah) and C ("Brunei") and if the strongly resembling form 'polyphyllus' is also included, then also once in area A (NW Sabah). All other forms (see names in Fig. 2) occur mixed throughout the phylogeny. This likely indicates that $C$. javensis is genetically and phenetically quite plastid, adapting (relatively quickly?) easily to varying environmental circumstances as long as these are in the more everwet areas, whereby similar forms can occur in very disjunct areas, that probably have a more or less similar habitat. This can be seen in Table 1 as various recognisable forms occur in different areas.

During glacial periods land bridges occurred, one ranges from NE Borneo via Mindanao to Luzon (e.g., Morley \& Flenley, 1987: fig. 5.5). Calamus javensis may have dispersed to Luzon via this bridge, but as the climate and soils differed the species adapted, which resulted in 'Form 2'. Similar changes, can for instance also be seen in Guioa pleuropteris (Blume) Radlk. (Sapindaceae), where the leaflets became much smaller with a different hair type then found on Borneo (van Welzen, 1989: fig. 110). Similar geoclines, indicative of the landbridge, are also present in two other Sapindaceae: Gloeocarpus patentivalvis (Radlk.) Radlk. (van Welzen, 1991) and Lepidopetalum perrottetii (Cambess.) Blume (van Welzen et al., 1992).

In conclusion, likely due to the lack of phylogenetic signal, it is obvious that the present analysis shows no historical biogeographic pattern behind the various recognisable forms in the $C$. javensis complex. Forms are very likely the result of adaptation to local circumstances, whereby more or less identical forms can develop under similar niche circumstances in disjunct areas. Exceptions are the 'acuminatus-polyphyllus' form and $C$. tenompokensis, which are present in nondisjunct areas.

\section{ACKNOWLEDGEMENTS}

We would like to express our gratitude to the Ministry of Research, Technology and Higher Education of the Republic of Indonesia (MENRISTEKDIKTI). The first author is supported by a doctoral scholarship from DIKTILeiden University joined scholarship from the Ministry of Research, Technology and Higher Education of the Republic of Indonesia (MENRISTEKDIKTI). This field trip of the first author was funded by the Alberta Mennega Stichting, Leiden University Funds (LUF) and Maatschappij voor Wetenschappelijk Onderzoek in de Tropen/ The Society for the Advancement of Research in the Tropics (Treub-Maatschappij). The second author also thanks the Treub-Maatschapij for supporting the Ornstein chair in Tropical Plant Biogeography. We extend our gratitude to reviewers for their review and useful comments on the manuscript.

\section{REFERENCES}

ATRIA, M., EURLINGS, M., BAKER, W. J., DRANSFIELD, J. \& VAN WELZEN, P. C. 2020. Phylogenetic analysis of the Calamus javensis complex (Arecaceae: Calamoideae) in Malesia. Blumea 65: 205-211.

ATRIA, M., VAN MIL, H., BAKER, W. J., DRANSFIELD, J. \& VAN WELZEN, P. C. 
2017. Morphometric analysis of the rattan Calamus javensis complex (Arecaceae: Calamoideae). Syst. Bot. 42: 494-506.

BAKER, W. J. 2015. A revised delimitation of the rattan genus Calamus (Arecaceae). Phytotaxa 197: 139-152.

BAKER, W. J., HEDDERSON, T. A. \& DRANSFIELD, J. 2000a. Molecular phylogenetics of Subfamily Calamoideae (Palmae) based on nrDNA ITS and cpDNA rps16 Intron Sequence Data. Molec. Phylogen. Evol. 14: 195-217.

BAKER, W. J., HEDDERSON, T. A. \& DRANSFIELD, J. 2000b. Molecular phylogenetics of Calamus (Palmae) based on 5S nrDNA spacer sequence data. Molec. Phylogen. Evol. 14: $218-231$.

BARFORD, A. S. \& DRANSFIELD, J. 2013. Arecaceae (Palmae). In: SANTISUK, T. \& LARSEN, K. (Eds.). Flora of Thailand 11, 3. The Forest Herbarium, Bangkok.

CANNON, H. C., MORLEY, R. J. \& BUSH, A. B. G. 2009. The current refugial rainforests of Sundaland are unrepresentative of their biogeographic past and highly vulnerable to disturbance. Proc. Natl. Acad. Sci. U.S.A. 106: 11188-11193.

HALL, R. 2013. The palaeogeography of Sunda-land and Wallacea since the Late Jurassic. J. Limnol. 72: $1-17$.

HENDERSON, A. 2020. A revision of Calamus (Arecaceae, Calamoideae, Calameae, Calaminae). Phytotaxa 445: 1-656.

JANSSENS, S. B., COUVREUR, T. L. P., MERTENS, A., DAUBY, G., DAGALLIER, L. P. M. J., VANDEN ABEELE, S., VANDELOOK, F., MASCARELLO, M., BEECKMAN, H., SOSEF, M., DROISSART, V., VAN DER BANK, M., MAURIN, O., HAWTHORNE, W., MARSHALL, C., RÉJOU-MÉCHAIN, M., BEINA, D., BAYA, F., MERCKX, V., VERSTRAETE, B. \& HARDY, O. 2020. A large-scale species level dated angiosperm phylogeny for evolutionary and ecological analysis. Biodiv. Data J. 8: e39677.
KRAMADIBRATA, P. 1992. A Revision of the Genus Calamus (Palmae) section Macropadus sensu Furtado. University of Reading, Reading. [PhD. Thesis].

MORLEY, R. J. \& FLENLEY, J. R. 1987. Late cainozoic vegetational and environmental changes in the Malay Archipelago. In: WHITMORE, T. C. (Ed.). Biogeographical Evolution of the Malay Archipelago. Oxford Science Publications, Oxford. Pp. 50-59.

RAES, N., CANNON, C. H., HIJMANS, R. J., PIESSENS, T., SAW, L. G., VAN WELZEN, P. C. \& SLIK, J. W. F. 2014. Historical distribution of Sundaland's Dipterocarp rainforests at Quaternary glacial maxima. Proc. Natl. Acad. Sci. U.S.A. 111: 16790-16795.

REE, R. H. \& SMITH, S. A. 2008. Maximum likelihood inference of geographic range evolution by dispersal, local extinction, and cladogenesis. Syst. Biol. 57: 4-14.

REE, R. H., MOORE, B. R., WEBB, C. O. \& DONOGHUE, M. J. 2005. A likelihood framework for inferring the evolution of geographic range on phylogenetic trees. Evolution 59: 2299-2311.

RONQUIST, F. 1997. Dispersal-vicariance analysis: a new approach to the quantification of historical biogeography. Syst. Biol. 46: 195-203.

VAN WELZEN, P. C. 1989. Guioa Cav. (Sapindaceae): Taxonomy, phylogeny, and historical biogeography. Leiden Bot. Ser. 12: 1-315.

VAN WELZEN, P. C. 1991. Gloeocarpus Radlk. (Sapindaceae) revised. Blumea 35: 389-392.

VAN WELZEN, P. C., PISKAUT, P. \& WINDADRI, F. I. 1992. Lepidopetalum Blume (Sapindaceae): taxonomy, phylogeny, and historical biogeography. Blumea 36: 439-465.

YU, Y., HARRIS, A. J., BLAIR, C. \& HE, X. J. 2015. RASP (Reconstruct ancestral state in phylogenies): a tool for historical biogeography. Molec. Phylogen. Evol. 87: 46-49. 